\title{
Desulfacinum hydrothermale sp. nov., a thermophilic, sulfate-reducing bacterium from geothermally heated sediments near Milos Island (Greece)
}

\author{
Stefan M. Sievert and Jan Kuever
} Author for correspondence: Jan Kuever. Tel: +49 4212028 734. Fax: +49 4212028580.
e-mail: jkuever@mpi-bremen.de

Department of Microbiology, MaxPlanck-Institute for Marine Microbiology, Celsiusstraße 1, D-28359, Bremen, Germany

\begin{abstract}
A thermophilic, sulfate-reducing bacterium, strain MT-96', was isolated from an active, marine, shallow-water hydrothermal vent system. It used a large variety of substrates, ranging from simple organic compounds to long-chain fatty acids, as electron donors. Autotrophic growth was possible with $\mathbf{H}_{2}$ and $\mathrm{CO}_{2}$ in the presence of sulfate. Sulfate, thiosulfate and sulfite were used as electron acceptors. Sulfur and nitrate were not reduced. Fermentative growth was obtained with pyruvate, but not with fumarate or malate. Substrate oxidation was usually complete, leading to production of $\mathrm{CO}_{2}$, but at high substrate concentrations acetate accumulated. The oval-shaped cells were $0.8-1.0 \mu \mathrm{m}$ in width and 1.5-2.5 $\mu \mathrm{m}$ in length. Cells were motile during the early-exponential-growth phase, but motility rapidly declined during later growth phases. Spores were not produced and cells stained Gram-negative. The temperature limits for growth were between 37 and $64^{\circ} \mathrm{C}$, with an optimum at $60^{\circ} \mathrm{C}$. Growth was observed at salinities ranging from 15 to $78 \mathrm{~g}$ $\mathrm{NaCl} \mathrm{I}^{-1}$, with optimum growth in the presence of $32-36 \mathrm{~g} \mathrm{NaCl} \mathrm{I}^{-1}$. This might reflect an adaptation to the elevated salinity of the hydrothermal fluid. The $\mathrm{G}+\mathrm{C}$ content of the DNA was $59.5 \mathrm{~mol} \%$. Vitamins or other supplements were not required. Based on the 165 rRNA gene sequence, strain MT-96 ${ }^{\top}$ belonged in the $\delta$-subclass of the Proteobacteria. Strain MT-96' was found to be phenotypically and phylogenetically related to Desulfacinum infernum ( $<95.3 \%$ sequence identity) and represents a new member of the genus Desulfacinum. The name Desulfacinum hydrothermale is proposed for this strain; the type strain is MT-96 ( = DSM 13146).
\end{abstract}

Keywords: Desulfacinum, thermophilic sulfate-reducing bacterium, hydrothermal vent, deep subsurface biosphere

\section{INTRODUCTION}

Most thermophilic, dissimilatory, sulfate-reducing bacteria are phylogenetically members of the Clostridium-Bacillus subphylum of the Gram-positive bacteria (Stackebrandt et al., 1997) or a deeply branching lineage within the domain Bacteria containing the genera Thermodesulfobacterium and Thermodesulfovibrio (Zeikus et al., 1983; Henry et al.,

Abbreviation: MPN, most probable number.

The GenBank accession number for the nearly complete 16S rRNA sequences of strains MT- $96^{\top}$ and $M 40 / 2$ CIV-2.3, and the partial sequence of strain M40/2 CIV-3.2 are AF170417, AF170418 and AF170420, respectively.
1994). Within the $\delta$-subclass of the Proteobacteria, which contains all other sulfate-reducing bacteria, only three thermophilic species are described. These are Desulfacinum infernum (Rees et al., 1995), Thermodesulforhabdus norvegicus (Beeder et al., 1995) and the incompletely described, alkane-oxidizing strain TD3 (Rueter et al., 1994); all were isolated from marine habitats and require marine or brackish water media for cultivation.

Two different habitats could be considered as ideal sites for marine thermophilic sulfate reducers. These are oil reservoirs located several kilometres below the sea floor, which have elevated temperatures and pressures (e.g. Stetter et al., 1993; Nilsen et al., 1996b), 
and hydrothermal vent systems (Jørgensen et al., 1990, 1992). In addition, a common deep subterranean biosphere might exist that supports the growth of these organisms as has been suggested by Gold (1992). Recently, data were presented that support such an idea (e.g. Deming \& Baross, 1993; L'Haridon et al., 1995; Nilsen et al., 1996b; Summit \& Baross, 1998; but see Stetter et al., 1993 for a different view). For example, the thermophilic, marine sulfate reducer Desulfacinum infernum and Thermodesulforhabdus norvegicus were isolated from enrichment cultures inoculated with formation water from North Sea oilfields (Rees et al., 1995; Beeder et al., 1995). A detailed study of the distribution of thermophilic, marine sulfate reducers in North Sea oilfield waters and oil reservoirs by using genus-specific, fluorescent antibodies showed a clear dominance of the genera Archaeoglobus and Thermodesulforhabdus, whereas thermophilic Desulfotomaculum spp. were only obtained from enrichment cultures (Nilsen et al., 1996a, b). In addition, several halophilic or halotolerant Desulfotomaculum spp. were isolated from various geothermally influenced, terrestrial subsurface habitats (Daumas et al., 1988; Nazina et al., 1989; Love et al., 1993; Fardeau et al., 1995; Liu et al., 1997; Tardy-Jacquenod et al., 1998).

The increased interest in thermophilic, sulfate-reducing bacteria has been strongly connected to their role and function during oil recovery, i.e. an enhanced sulfide production and stimulated corrosion due to the activities of sulfate-reducing bacteria. Little is known about the natural role of thermophilic sulfate reducers. Since the isolation of the hydrocarbon-degrading strain TD3 from a deep-sea vent site in the Guaymas Basin, the substrate spectra of thermophilic, sulfatereducing bacteria has been extended and now includes alkanes, which were originally thought to be recalcitrant under anoxic conditions (Rueter et al., 1994). In this paper we describe a thermophilic isolate, MT$96^{\mathrm{T}}$, which was obtained from a shallow, submarine hydrothermal vent. The data presented in this communication further suggest that members of the thermophilic genera Thermodesulforhabdus and Desulfacinum are, indeed, part of a subsurface microbial community, as originally proposed by Nilsen et al. (1996b).

\section{METHODS}

Source of organism. Strain MT- $96^{\mathrm{T}}$ was isolated from most probable number (MPN) dilution series that were performed to investigate the horizontal and vertical distribution of sulfate-reducing bacteria at a shallow, submarine hydrothermal vent located in Palaeochori Bay, which is a sandy bay in the south-eastern part of the Greek island of Milos in the Aegean Sea (Sievert et al., 1999).

Media and culture conditions. The MPN series was performed as described by Sievert et al. (1999). Artificial, bicarbonate-buffered seawater medium, as defined for sulfate-reducing bacteria, was used (Widdel \& Bak, 1992); $10 \mathrm{mM}$ acetate as carbon source, non-chelated trace element mixture number 1, vitamins, and a tungstate and selenite solution were added (Widdel \& Bak, 1992). For isolation and routine cultivation, acetate was replaced by lactate. Media were reduced with sulfide and prepared as described by Widdel \& Bak (1992). Pure cultures were obtained by repeated use of deep agar dilution series (Widdel \& Bak, 1992). Substrate utilization was determined by adding the carbon and energy sources from sterile stock solutions, and the preparations were incubated for about 3 weeks. To test the capability for autotrophic growth, cultures were grown with a headspace of $80 \% \mathrm{H}_{2} / 20 \% \mathrm{CO}_{2}$ at an overpressure of $101.29 \mathrm{kPa}$. The temperature range for growth was determined by incubation in a temperature gradient block from 35 to $80^{\circ} \mathrm{C}$ in increments of $2-4^{\circ} \mathrm{C}$. The $\mathrm{pH}$ range for growth was determined in mineral medium with $\mathrm{pH}$ from $5 \cdot 0$ to $9 \cdot 0$. The dependence of growth on the concentration of $\mathrm{NaCl}$ was determined in mineral medium with $\mathrm{NaCl}$ concentrations from 0 to $82 \mathrm{~g} \mathrm{NaCl} \mathrm{l}^{-1}$.

Chemical and biochemical characterization. The presence of desulfoviridin was tested as described by Postgate (1956). The $\mathrm{G}+\mathrm{C}$ content was determined by $\mathrm{M}$. Nagel (Fachhochschule Bremerhaven, Germany) by HPLC as described previously (Brinkhoff et al., 1999). Lambda DNA was used for final correction of the values.

PCR amplification and sequencing of the 16S rRNA gene. To amplify the almost complete $16 \mathrm{~S}$ rRNA encoding gene (1500 bp) of strains MT-96 ${ }^{\mathrm{T}}$, M40/2 CIV-2.3 and M40/2 CIV-3.2, primers GM3F and GM4R were used in a 35 cycle PCR with an annealing temperature of $40^{\circ} \mathrm{C}$ (Muyzer et al., 1995). PCR products were purified by using the QIAquick Spin PCR Purification kit (Qiagen) as described by the manufacturer. The Taq DyeDeoxy Terminator Cycle Sequencing kit (Applied Biosystems) was used to directly sequence the PCR products according to the protocol provided by the manufacturer. The sequencing primers were described by Buchholz-Cleven et al. (1997). The sequence reaction mixtures were electrophoresed on an Applied Biosystems 373S DNA sequencer.

Phylogenetic analyses of 16S rRNA gene sequence data. The sequences were loaded into the 16S rRNA sequence database of the Technical University Munich using the program package ARB (O. Strunk and others, http://www.mikro. biologie.tu-muenchen.de). The tool ARB-ALIGN was used for sequence alignment. The alignment was visually inspected and corrected manually. Tree topologies were evaluated by performing maximum-parsimony, neighbourjoining and maximum-likelihood analyses. Only sequences with at least 1400 nucleotides were used for the calculation of different trees. The partial sequence of strain M40/2 CIV3.2 (1268 nucleotides) was added to the reconstructed tree by applying parsimony criteria without allowing changes in the overall tree topology. The strain designations and nucleotide sequence accession numbers are as follows: Desulfacinum infernum ACM 3991 ${ }^{\mathrm{T}}$, L27426; Thermodesulforhabdus norvegicus DSM 9990 ${ }^{\mathrm{T}}$, U25627; Desulforhabdus amnigenus DSM 10338 ${ }^{\mathrm{T}}$, X83274; strain TD3, X80922; Desulfohalobium retbaense DSM 5692 ${ }^{\mathrm{T}}$, U48244; Desulforhopalus vacuolatus DSM 9700" ${ }^{\mathrm{T}}$ L42613; Desulfobacter postgatei DSM 2034 ${ }^{\mathrm{T}}$ M26633; 'Desulfobacterium niacini' DSM $2650^{\mathrm{T}}$, U51845; Desulfosarcina variabilis DSM 2060 ${ }^{\mathrm{T}}$, M34407; Syntrophus buswellii DSM 2612 ${ }^{\mathrm{T}}$, X85131; Desulfomonile tiedjei ATCC 49306 ${ }^{\mathrm{T}} \mathrm{M} 26635$; Syntrophobacter wolinii DSM 2805 ${ }^{\mathrm{T}}$, X70905; Desulfuromonas acetoxidans ATCC $11775^{\mathrm{T}}$, X80725; Desulfovibrio halophilus DSM 5663 ${ }^{\mathrm{T}}$, U48243; Desulfovibrio desulfuricans ATCC 
27774, M34113; Desulfovibrio gabonensis DSM 10636 ${ }^{\mathrm{T}}$, U31080. The sequence accession number of clone OPB33 is AF026987.

\section{RESULTS}

\section{Enrichment and isolation}

Serial MPN dilutions were performed using media containing $10 \mathrm{mM}$ acetate as the only carbon source and inocula from different layers of the sediment (Sievert et al., 1999). Strain MT-96 $6^{\mathrm{T}}$ was isolated from the $10^{-2}$ dilution of a sample that came from the sediment layers between 2 and $3 \mathrm{~cm}$ at a distance of $10 \mathrm{~cm}$ from the vent centre (Sievert et al., 1999). The in situ temperature of this sediment layer ranged from 50 to $60{ }^{\circ} \mathrm{C}$ and the $\mathrm{pH}$ was approximately $5 \cdot 0$ (Sievert et al., 1999). The mean composition of the discharged gases from different seeps in Palaeochori Bay was $80.5 \%$ (v/v) $\mathrm{CO}_{2}, 1.2 \%$ (v/v) $\mathrm{H}_{2} \mathrm{~S}, 0.8 \%$ (v/v) $\mathrm{CH}_{4}$ and $0.4 \%(\mathrm{v} / \mathrm{v}) \mathrm{H}_{2}$ (Dando et al., 1995). The chemically reduced hydrothermal fluid had an elevated salinity of up to $58 \%$, compared to $39 \%$ of the ambient seawater (Thiermann et al., 1997). After 2-3 weeks incubation, formation of sulfide and growth of small, oval rods were observed. Following several transfers into liquid media, a pure culture was obtained by repeated agar dilution series using lactate as electron donor and sulfate as electron acceptor. Previous experiments had shown that lactate allows faster growth. Besides strain MT-96 ${ }^{\mathrm{T}}$, which was isolated from a vent site at a water depth of $8 \mathrm{~m}$, two other thermophilic, sulfate-reducing isolates were obtained from a vent site that was located offshore of the southeastern part of the island of Milos (Greece) at $120 \mathrm{~m}$ water depth using the same procedures as indicated above. These samples were obtained on a cruise with the $\mathrm{R} / \mathrm{V}$ Meteor during leg M40/2. A MPN series with acetate as single carbon source inoculated with sediment from a horizon $45-65 \mathrm{~mm}$ below the surface (in situ temperature $60-70{ }^{\circ} \mathrm{C}$ ) showed growth at the $10^{-2}$ and $10^{-3}$ dilutions. Strains M40/2 CIV-2.3 and M40/2 CIV-3.2 were isolated from the $10^{-2}$ and $10^{-3}$ dilutions, respectively. Further physiological characterization of these two strains was not carried out, but they were included in the phylogenetic analysis since they clustered with MT- $96^{\mathrm{T}}$ and Thermodesulforhabdus norvegicus. In contrast to the shallow-water hydrothermal vent, the surface layer of the deeper vent site was covered with large, nonmotile, filamentous sulfur-oxidizing bacteria, which were attached to sediment particles. The in situ temperature at the surface was around $45^{\circ} \mathrm{C}$.

\section{Cell morphology}

Cells of strain MT-96 ${ }^{\mathrm{T}}$ grown with lactate or acetate and sulfate were oval or short rods measuring 0.8 $1.0 \times 1 \cdot 5-2.5 \mu \mathrm{m}$ (Fig. 1). Cells occurred singly or in pairs. Spore formation was absent. Cells were motile only during the early-exponential-growth phase. In

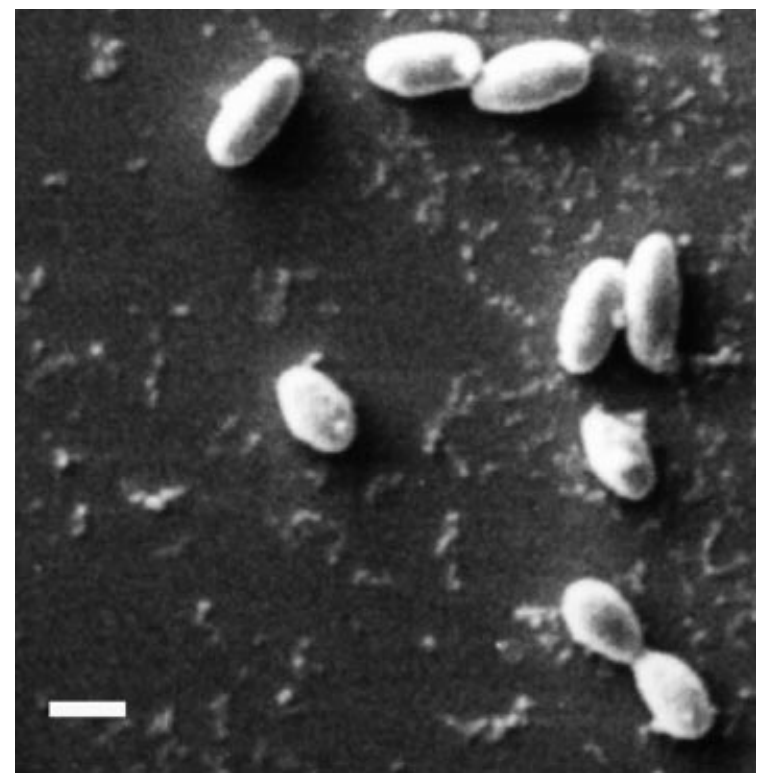

Fig. 1. Scanning electron micrograph of strain $M T-96^{\top}$ showing the typical oval or rod-shaped cell form. Bar, $1 \mu \mathrm{m}$.

later growth phases, motility was only occasionally observed. Very often, only a few cells were motile.

\section{DNA base ratio}

The $\mathrm{G}+\mathrm{C}$ content of the DNA was $59 \cdot 5 \mathrm{~mol} \%$.

\section{Physiological properties}

The optimum growth temperature of strain MT- $96^{\mathrm{T}}$ was determined to be $60^{\circ} \mathrm{C}$. No growth was observed at temperatures higher than $64^{\circ} \mathrm{C}$ and lower than $37^{\circ} \mathrm{C}$. At temperatures less than $44{ }^{\circ} \mathrm{C}$, cells aggregated into flocs. The $\mathrm{pH}$ range was between 6.0 and 7.5 with an optimum at $\mathrm{pH} 7 \cdot 0$. The optimum $\mathrm{NaCl}$ concentration for growth was between 32 and $36 \mathrm{~g}^{-1}$. Growth was obtained at salinities ranging from 15 to $78 \mathrm{~g} \mathrm{NaCl}^{-1}$. Vitamins were not essential for growth (six consecutive transfers in vitamin-free medium). Desulfoviridin was absent in strain MT- $96^{\mathrm{T}}$.

Strain MT-96 ${ }^{\mathrm{T}}$ used the following compounds as electron donors and carbon sources in the presence of $10 \mathrm{mM}$ sulfate [added substrate concentrations (mM) are given in parentheses]: hydrogen plus carbon dioxide $(80 \% / 20 \%, \mathrm{v} / \mathrm{v})$ (four consecutive transfers without organic substrate; in medium with $\mathrm{N}_{2} / \mathrm{CO}_{2}$ as headspace no growth was observed), formate (10), acetate (10), propionate (10), butyrate (5), isobutyrate (5), valerate (5), isovalerate (5), octanoate $(2 \cdot 5)$, decanoate $(0 \cdot 5)$, dodecanoate $(0 \cdot 5)$, hexadecanoate $(1)$, octadecanoate (1), ethanol (10), propanol (10), butanol (10), hexanol (5), lactate (10), pyruvate (10), alanine (10), yeast extract $(0 \cdot 1 \%$ and $0 \cdot 01 \%)$.

The following substrates were tested, but not utilized: fructose (5), glucose (5), sucrose (5), malate (10), 


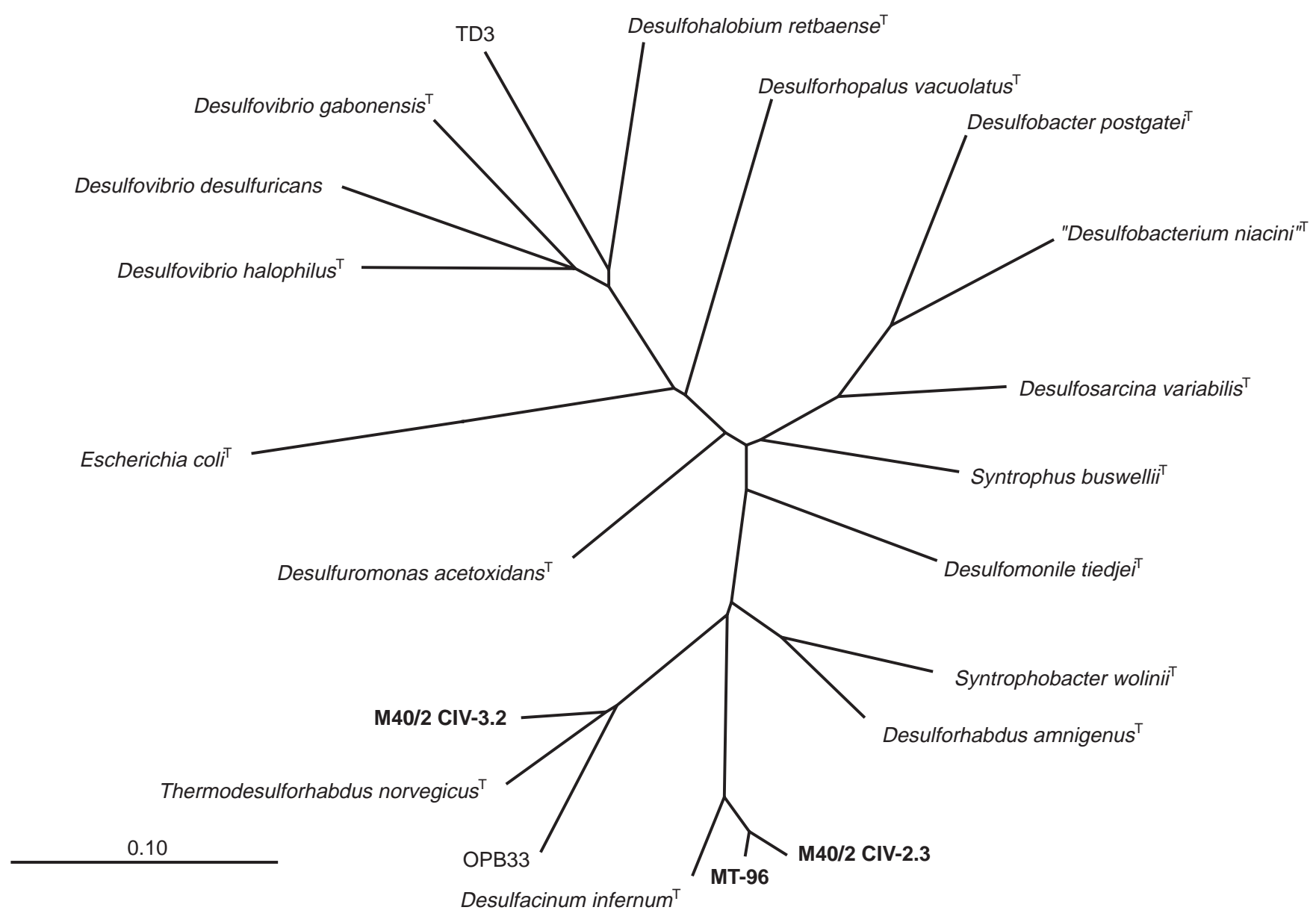

Fig. 2. Maximum-likelihood tree based on 1426 positions of nearly full length $16 \mathrm{~S}$ rRNA sequences from 20 bacteria and one clonal sequence (OPB33) from the $\delta$-subclass of the Proteobacteria, rooted with Escherichia coli ( $\gamma$-subclass of the Proteobacteria). All trees constructed with other reconstruction algorithms (neighbour-joining and parsimony) resulted in the same overall topology. In bootstrap analysis using neighbour-joining and parsimony criteria, the branching leading to the Desulfacinum-Thermodesulforhabdus cluster was supported with values of 100 (data not shown). The partial sequence of strain M40/2 CIV-3.2 was inserted into the tree by applying parsimony criteria without allowing for changes in the overall tree topology. Scale-bar represents 10 substitutions per 100 nucleotides. T indicates type strain; see Methods for strain and nucleotide sequence accession numbers.

fumarate (10), succinate (10), citrate (10), glycerol (10), glutamate (10), benzoate (2), $p$-cresol (1), hexadecane (1), crude oil $(0 \cdot 001 \%)$.

Sulfate, sulfite and thiosulfate were used as electron acceptors. Sulfur and nitrate did not serve as electron acceptor. Pyruvate allowed slow growth by fermentation.

The minimum doubling time with lactate was $23 \mathrm{~h}$. Increased substrate concentrations resulted in the production of acetate, which was released into the medium. When grown on $20 \mathrm{mM}$ lactate, $2-3 \mathrm{mM}$ acetate and $0.5 \mathrm{mM}$ propionate were observed.

\section{Phylogenetic analyses}

The 16S rRNA gene sequence of strain MT- $96^{\mathrm{T}}$ shared between 80 and $95.3 \%$ identity with the 16S rRNA gene sequences of other sulfate reducers of the $\delta$ - subclass of the Proteobacteria (data not shown). The phylogenetic positions of strains MT-96 ${ }^{\mathrm{T}}$, M40/2 CIV2.3 and M40/2 CIV-3.2 are shown in Fig. 2. All of them are members of the $\delta$-subclass of the Proteobacteria. Comparative phylogenetic analyses revealed that strain MT- $96^{\mathrm{T}}$ is a member of the genus Desulfacinum and is closely related to Desulfacinum infernum (95.3\% 16S rRNA sequence identity), which is the only species of this genus reported to date (Fig. 2). Strain M40/2 CIV-2.3 was closely related to MT$96^{\mathrm{T}}(98 \cdot 2 \%$ 16S rRNA sequence identity), whereas strain M40/2 CIV-3.2 clustered with Thermodesulforhabdus norvegicus $(94.9 \%$ 16S rRNA sequence identity).

\section{DISCUSSION}

The isolate strain MT- $96^{\mathrm{T}}$ is a thermophilic, sulfatereducing bacterium that can use a large variety of 
Table 1. Comparison of selected characteristics of strain MT-96 ${ }^{\top}$, Desulfacinum infernum, Thermodesulforhabdus norvegicus, strain TD3 and Desulforhabdus amnigenus

All strains contained desulfoviridin and usually showed complete substrate oxidation. Data were obtained from Rueter $e t$ al. (1994); Beeder et al. (1995); Rees et al. (1995); Oude Elferink et al. (1995); and Ehrenreich (1996).

\begin{tabular}{|c|c|c|c|c|c|}
\hline Character & Strain MT-96 ${ }^{\mathrm{T}}$ & $\begin{array}{l}\text { Desulfacinum } \\
\text { infernum }\end{array}$ & $\begin{array}{c}\text { Thermodesulforhabdus } \\
\text { norvegicus }\end{array}$ & Strain TD3 & $\begin{array}{c}\text { Desulforhabdus } \\
\text { amnigenus }\end{array}$ \\
\hline Morphology & Oval & Oval & Rod & Rod & Rod \\
\hline Size $(\mu \mathrm{m})$ & $0 \cdot 8-1 \cdot 0 \times 1 \cdot 5-2.5$ & $1 \cdot 5 \times 2 \cdot 5-3 \cdot 0$ & $1.0 \times 2.5$ & $0 \cdot 8-1 \cdot 0 \times 2 \cdot 0-3 \cdot 5$ & $1.4-1.9 \times 2.5-3.4$ \\
\hline Motility & $+^{*}$ & - & $+\dagger$ & $-/+$ & - \\
\hline $\mathrm{G}+\mathrm{C}$ content $(\mathrm{mol} \%)$ & $59 \cdot 5$ & $64 \cdot 0$ & $51 \cdot 0$ & $37 \cdot 4$ & $52 \cdot 5$ \\
\hline Optimal salinity $\left(\mathrm{g} \mathrm{l}^{-1}\right)$ & $32-36$ & 10 & 16 & $\mathrm{NR}$ & 0 \\
\hline $\begin{array}{l}\text { Optimal temperature } \\
\left({ }^{\circ} \mathrm{C}\right)\end{array}$ & 60 & 60 & 60 & 60 & 37 \\
\hline \multicolumn{6}{|l|}{ Electron donors: } \\
\hline $\mathrm{H}_{2}+\mathrm{CO}_{2}$ & $+\ddagger$ & $+\ddagger$ & - & - & $+t$ \\
\hline Formate & $+\ddagger$ & $+\ddagger$ & - & - & $+\ddagger$ \\
\hline Acetate & + & + & + & - & + \\
\hline $\begin{array}{l}\text { Fatty acids (no. } \\
\text { C atoms) }\end{array}$ & $\begin{array}{c}3-5,8,10,12 \\
16,18\end{array}$ & $3-18$ & $4-18$ & $4-8,12,16,18$ & $3-4$ \\
\hline Isobutyrate & + & + & NR & $\mathrm{NR}$ & + \\
\hline Isovalerate & + & + & NR & NR & - \\
\hline Ethanol & + & + & + & - & + \\
\hline Lactate & + & + & + & - & + \\
\hline Pyruvate & + & + & + & - & + \\
\hline Fumarate & - & + & + & - & - \\
\hline Succinate & - & + & + & - & - \\
\hline Malate & - & + & + & - & - \\
\hline Benzoate & - & - & - & - & - \\
\hline Hexadecane & - & - & - & + & NR \\
\hline Others & $\begin{array}{l}\text { Propanol, butanol, } \\
\text { hexanol, alanine }\end{array}$ & $\begin{array}{c}\text { Propanol, butanol, } \\
\text { hexanol, alanine }\end{array}$ & $\mathrm{NR}$ & Alkanes & Propanol, butanol \\
\hline $\begin{array}{l}\text { Fermentative growth } \\
\text { on pyruvate }\end{array}$ & + & + & - & $\mathrm{NR}$ & - \\
\hline \multicolumn{6}{|l|}{ Electron acceptors: } \\
\hline Sulfate & + & + & + & + & + \\
\hline Sulfite & + & + & + & NR & + \\
\hline Sulfur & - & - & - & $\mathrm{NR}$ & - \\
\hline Thiosulfate & + & + & - & - & + \\
\hline Nitrate & - & - & - & $\mathrm{NR}$ & - \\
\hline $\begin{array}{l}\text { Growth factor } \\
\text { requirement }\end{array}$ & None & Vitamins & None & NR & NR \\
\hline
\end{tabular}

NR, Not reported.

* Cells are motile during early-exponential-growth phase, but motility can rapidly decline during growth.

$\dagger$ Single polar flagellum.

$\$$ Autotrophic growth.

substrates as electron donors. The ability to use acetate and propionate and to grow autotrophically with $\mathrm{H}_{2}$ and $\mathrm{CO}_{2}$ is shared with its closest relative, Desulfacinum infernum (Rees et al., 1995) and several mesophilic sulfate reducers (Widdel \& Bak, 1992). The substrates are usually completely oxidized to $\mathrm{CO}_{2}$, but increased substrate concentrations can lead to an incomplete oxidation of organic substrates. For the utilization of fatty acids, this might be a result of a CoA transferase reaction as proposed for Desulfo- bacterium autotrophicum (Schauder et al., 1986), whereas acetate and propionate excretion after growth on lactate might be caused by partial fermentation of the lactate via a randomizing succinate pathway as described for Desulfobulbus propionicus (Stams et al., 1984).

The 16S rRNA gene sequence analyses presented in this study demonstrate that strain MT- $96^{\mathrm{T}}$ is a member of the genus Desulfacinum with Desulfacinum infernum 
as its closest relative $(95 \cdot 3 \%$ 16S rRNA sequence identity). Its physiological properties (Table 1), in combination with the results of the 16S rRNA gene sequence comparison, indicate that strain MT- $96^{\mathrm{T}}$ represents a novel species within the genus Desulfacinum. We propose the name Desulfacinum hydrothermale sp. nov. for this strain.

\section{Ecological relevance}

On the basis of its growth characteristics, i.e. its temperature optimum and its salt tolerance, strain MT- $96^{\mathrm{T}}$ seemed to be well adapted to the environment from which it was isolated. However, the $\mathrm{pH}$ range determined for the isolate does not cover the $\mathrm{pH}$ measured in situ at the sampling site. A possible explanation could be a toxic effect of $\mathrm{H}_{2} \mathrm{~S}$ at low $\mathrm{pH}$ within the batch cultures, which would not occur in the natural environment because of interaction with ferrous iron or by dilution due to exchange with the overlying water. However, strain MT- $96^{\mathrm{T}}$ may grow in microniches with favourable environmental conditions (Fortin et al., 1996). The fractionation of sulfur isotopes during dissimilatory sulfate reduction obtained in batch cultures was within the range found for mesophilic sulfate reducers and reflected the in situ sulfur isotopic composition of the sediments (Böttcher et al., 1999).

The finding of members of the genus Desulfacinum, represented by MT-96 $6^{\mathrm{T}}$ and M40/2 CIV-2.3, and of the genus Thermodesulforhabdus, represented by M40/2 CIV-3.2, at both vent sites indicates an important role for the degradation of organic compounds by thermophilic sulfate reduction at hydrothermal vents. The presence of thermophilic sulfate reducers has also been shown for a deep-sea vent site in Guaymas Basin (Jørgensen et al., 1990, 1992). In addition, it seems plausible to assume that at least strain MT- $96^{\mathrm{T}}$ contributes to primary production at the shallow-water vent site by growing with $\mathrm{H}_{2}$ and $\mathrm{CO}_{2}$ because both substances are constituents of the hydrothermal fluid (Dando et al., 1995). Our data further support the idea of Nilsen et al. (1996b), who proposed that species of the genera Thermodesulforhabdus and Desulfacinum are members of a deep hot biosphere (sensu Gold, 1992) that contains thermophilic and hyperthermophilic micro-organisms. However, until now these two genera had not been isolated from any environment other than oil reservoirs. The present findings extend their habitat range to marine hydrothermal vents. Moreover, at least Thermodesulforhabdus seems also to be present in Obsidian Pool, a freshwater hot spring in Yellowstone National Park (Hugenholtz et al., 1998). The sequence OPB33 is closely affiliated with Thermodesulforhabdus norvegicus (Fig. 1) and was the second most abundant sequence in the clone library (Hugenholtz et al., 1998). This suggests that these populations play an important role iIn this environment. Whilst this argues for the existence for a common subterranean biosphere, the presence of Thermodesulforhabdus norvegicus and Desulfacinum infernum in oilfields could also be due to an intrusion of seawater that contained cells derived form hydrothermal sources and subsequent growth in the reservoir (Stetter et al., 1993). There are only a few descriptions of thermophiles from deep-sea hydrothermal vents with maximal growth temperatures below $80{ }^{\circ} \mathrm{C}$, although these organisms are thought to be abundant (Baross \& Deming, 1995). Thus, it should be worthwhile to look for the presence of members of the Desulfacinum-Thermodesulforhabdus cluster at deep-sea vents, which are also thought to provide a window into the subsurface biosphere (Deming \& Baross, 1993; Holden et al., 1998; Summit \& Baross, 1998).

\section{Description of Desulfacinum hydrothermale sp. nov.}

Desulfacinum hydrothermale (hy.dro.ther.ma'le. Gr. n. hydor water; Gr. n. thermos heat; M.L. neut. adj hydrothermale pertaining to hot water, i.e. to hydrothermal vents).

Cells are oval or short rods, $0.8-1.0$ by $1.5-2.5 \mu \mathrm{m}$. Spore formation is absent. Cells are motile, but motility can rapidly decline. Gram stain reaction of cells is negative. Strict anaerobe. Growth on $\mathrm{H}_{2} / \mathrm{CO}_{2}$, formate, acetate, propionate, butyrate, isobutyrate, valerate, isovalerate, octanoate, decanoate, dodecanoate, hexadecanoate, octadecanoate, ethanol, propanol, butanol, hexanol, lactate and pyruvate. Substrate oxidation is usually complete, leading to production of $\mathrm{CO}_{2}$, but at high substrate concentrations acetate can accumulate. Electron acceptors used are sulfate, sulfite and thiosulfate; nitrate and sulfur are not used. Slow fermentative growth on pyruvate. Addition of at least $15 \mathrm{~g} \mathrm{NaCl}^{-1}$ is necessary. Optimum $\mathrm{NaCl}$ concentration for growth is between 32 and $36 \mathrm{~g} \mathrm{l}^{-1}$. $\mathrm{NaCl}$ is tolerated up to $78 \mathrm{~g} \mathrm{l}^{-1}$. Vitamins are not required for growth. Temperature requirements: $T_{\min }, 37^{\circ} \mathrm{C} ; T_{\text {opt }}, 60^{\circ} \mathrm{C} ; T_{\max }, 64^{\circ} \mathrm{C}$. The $\mathrm{pH}$ range for growth is $6 \cdot 0-7 \cdot 5$; the $\mathrm{pH}$ optimum is $7 \cdot 0$. The $\mathrm{G}+\mathrm{C}$ content of the DNA is $59 \cdot 5 \mathrm{~mol} \%$. The GenBank accession number for the 16S rRNA gene sequence is AF170417. The type strain is MT-96 ${ }^{\mathrm{T}}$ (= DSM 13146).

\section{Emended description of the genus Desulfacinum (Rees et al. 1995, 88).}

The sentence regarding motility should be changed to: 'Oval cells, which may be motile or non-motile'.

\section{ACKNOWLEDGEMENTS}

We are grateful to Susanne Menger and Wiebke Ziebis for scuba diving and sampling, and to the mechanical workshop of the MPI for building the sampling devices. We further thank Matthias Nagel for determining the $\mathrm{G}+\mathrm{C}$ content, Alexander Galushko for help with HPLC analysis, Ingrid 
Kunze for technical assistance, Heike Stevens for preparing the electron micrograph and Tim Ferdelman for linguistic improvements to the manuscript. Special thanks goes to the participants of the EU-funded project 'Hydrothermal Fluxes and Biological Production in the Aegean' for their various support and help. S.M.S. also thanks the scientific party and the crew of R/V Meteor cruise M40/2 for support and an enjoyable stay on board during work at sea. Thanks are due to the Greek Ministry of Culture for diving permission to undertake these studies.

This work was funded by the EU under MAST CT-95-0021 and by the Max-Planck Society, Munich (Germany). Meteor cruise $40 / 2$ was supported by the German Science Foundation.

\section{REFERENCES}

Baross, J. A. \& Deming, J. W. (1995). Growth at high temperatures: isolation and taxonomy, physiology, and ecology. In Microbiology of Deep-sea Hydrothermal Vents, pp. 169-217. Edited by D. M. Karl. Boca Raton, FL: CRC Press.

Beeder, J., Torsvik, T. \& Lien, T. (1995). Thermodesulforhabdus norvegicus gen. nov., sp. nov., a novel thermophilic sulfatereducing bacterium from oil field water. Arch Microbiol 164, 331-336.

Böttcher, M. E., Sievert, S. M. \& Kuever, J. (1999). Fractionation of sulfur isotopes during dissimilatory reduction of sulfate by a thermophilic gram-negative bacterium at $60^{\circ} \mathrm{C}$. Arch Microbiol 172, 125-128.

Brinkhoff, T., Muyzer, G., Wirsen, C. O. \& Kuever, J. (1999). Thiomicrospira kuenenii sp. nov. and Thiomicrospira frisia sp. nov., two mesophilic obligately chemolithotrophic sulfuroxidizing bacteria isolated from an intertidal mud flat. Int $J$ Syst Bacteriol 49, 385-392.

Buchholz-Cleven, B. E. E., Ratunde, B. \& Straub, K. L. (1997). Screening for genetic diversity of isolates of anaerobic Fe(II)oxidizing bacteria using DGGE and whole-cell hybridization. Syst Appl Microbiol 20, 301-309.

Dando, P. R., Hughes, J. A., Leahy, Y., Niven, S. J., Taylor, L. J. \& Smith, C. (1995). Gas venting rates from submarine hydrothermal areas around the island of Milos, Hellenic Volcanic Arc. Cont Shelf Res 15, 913-929.

Daumas, S., Cord-Ruwisch, R. \& Garcia, J. L. (1988). Desulfotomaculum geothermicum sp. nov., a thermophilic, fatty aciddegrading, sulfate-reducing bacterium isolated with $\mathrm{H}_{2}$ from geothermal ground water. Antonie Leeuwenhoek 54, 165-178.

Deming, J. W. \& Baross, J. A. (1993). Deep-sea smokers: windows to a subsurface biosphere? Geochim Cosmochim Acta 57, 3219-3230.

Ehrenreich, P. (1996). Anaerobes Wachstum neuartiger sulfatreduzierender und nitratreduzierender Bakterien auf $n$-Alkanen und Erdöl. PhD thesis, University of BremeSOTO.

Fardeau, M.-L., Ollivier, B., Patel, B. K. C., Dwivedi, P., Ragot, M. \& Garcia, J.-L. (1995). Isolation and characterization of a thermophilic sulfate-reducing bacterium, Desulfotomaculum thermosapovorans sp. nov. Int J Syst Bacteriol 45, 218-221.

Fortin, D., Davis, B. \& Beveridge, T. J. (1996). Role of Thiobacillus and sulfate-reducing bacteria in iron biocycling in oxic and acidic mine tailings. FEMS Microbiol Ecol 21, 11-24.

Gold, T. (1992). The deep, hot biosphere. Proc Natl Acad Sci 89, 6045-6049.
Henry, E. A., Devereux, R., Maki, J. S., Gilmour, C. C., Woese, C. R., Mandelco, L., Schauder, R., Remsen, C. C. \& Mitchell, R. (1994). Thermodesulfovibrio yellowstonii, gen. nov. and sp. nov.: its phylogenetic relationship to Thermodesulfobacterium commune and their origins deep within the bacterial domain. Arch Microbiol 161, 62-69.

Holden, J. F., Summit, M. \& Baross, J. A. (1998). Thermophilic and hyperthermophilic microorganisms in $3-30{ }^{\circ} \mathrm{C}$ hydrothermal fluids following a deep-sea volcanic eruption. FEMS Microbiol Ecol 25, 33-41.

Hugenholtz, P., Pitulle, C., Hershberger, K. L. \& Pace, N. R. (1998). Novel division level bacterial diversity in a Yellowstone hot spring. J Bacteriol 180, 366-376.

Jørgensen, B. B., Zawacki, L. X. \& Jannasch, H. W. (1990). Thermophilic bacterial sulfate reduction in deep-sea sediments at the Guaymas Basin hydrothermal vent site (Gulf of California). Deep-Sea Res 37, 695-710.

Jørgensen, B. B., Isaksen, M. F. \& Jannasch, H. W. (1992). Bacterial sulfate reduction above $100{ }^{\circ} \mathrm{C}$ in deep-sea hydrothermal vent sediments. Science 258, 1756-1757.

L'Haridon, S. L., Reysenbach, A.-L., Glenat, P., Prieur, D. \& Jeanthon, C. (1995). Hot subterranean biosphere in a continental oil reservoir. Nature 377, 223-224.

Liu, Y., Karnauchow, T. M., Jarrell, K. F., Balkwill, D. L., Drake, G. R., Ringelberg, D., Clarno, R. \& Boone, D. R. (1997). Description of two thermophilic Desulfotomaculum spp., Desulfotomaculum putei sp. nov., from a deep terrestrial subsurface, and Desulfotomaculum luciae sp. nov., from a hot spring. Int J Syst Bacteriol 47, 615-621.

Love, C. A., Patel, B. K. C., Nichols, P. D. \& Stackebrandt, E. (1993). Desulfotomaculum australicum sp. nov., a thermophilic sulfatereducing bacterium isolated from the Great Artesian Basin of Australia. Syst Appl Microbiol 16, 244-251.

Muyzer, G., Teske, A., Wirsen, C. O. \& Jannasch, H. W. (1995). Phylogenetic relationships of Thiomicrospira species and their identification in deep-sea hydrothermal vent samples by denaturing gradient gel electrophoresis of $16 \mathrm{~S} \mathrm{rDNA}$ fragments. Arch Microbiol 164, 165-172.

Nazina, T. N., Ivanova, A. E., Kanchaveli, L. P. \& Rozanova, E. P. (1989). A new spore-forming thermophilic methylotrophic bacterium, Desulfotomaculum kuznetsovii sp. nov. Microbiology (English translation of Mikrobiologiya) 57, 659-663.

Nilsen, R. K., Torsvik, T. \& Lien, T. (1996a). Desulfotomaculum thermocisternum $\mathrm{sp}$. nov., a sulfate reducer isolated from a hot North Sea oil reservoir. Int J Syst Bacteriol 46, 397-402.

Nilsen, R. K., Beeder, J., Thorenson, T. \& Torsvik, T. (1996b). Distribution of thermophilic marine sulfate reducers in North Sea oil field waters and oil reservoirs. Appl Environ Microbiol 62, 1793-1798.

Oude Elferink, S. J. W. H., Maas, R. N., Harmsen, H. J. M. \& Stams, A. J. M. (1995). Desulforhabdus amnigenus gen. nov., sp. nov., a sulfate reducer isolated from anaerobic granular sludge. Arch Microbiol 164, 119-124.

Postgate, J. R. (1956). Cytochrome $c_{3}$ and desulphoviridin; pigments of the anaerobe Desulfovibrio desulphuricans. $J$ Gen Microbiol 14, 545-572.

Rees, G. N., Grassia, G. S., Sheehy, A. J., Dwivedi, P. P. \& Patel, B. K. C. (1995). Desulfacinum infernum gen. nov., sp. nov., a thermophilic sulfate-reducing bacterium from a petroleum reservoir. Int J Syst Bacteriol 45, 85-89.

Rueter, P., Rabus, R., Wilkes, H., Aeckersberg, F., Rainey, F. A., 
Jannasch, H. W. \& Widdel, F. (1994). Anaerobic oxidation of hydrocarbon in crude oil by new types of sulphate-reducing bacteria. Nature 372, 455-457.

Schauder, R., Eikmanns, B., Thauer, R. K., Widdel, F. \& Fuchs, G. (1986). Acetate oxidation to $\mathrm{CO}_{2}$ in anaerobic bacteria via a novel pathway not involving reactions of the citric acid cycle. Arch Microbiol 145, 162-172.

Sievert, S. M., Brinkhoff, T., Muyzer, G., Ziebis, W. \& Kuever, J. (1999). Spatial heterogeneity of bacterial populations along an environmental gradient at a shallow submarine hydrothermal vent near Milos Island (Greece). Appl Environ Microbiol 65, 3834-3842.

Stackebrandt, E., Sproer, C., Rainey, F. A., Burghardt, J., Päuker, O. \& Hippe, H. (1997). Phylogenetic analysis of the genus Desulfotomaculum: evidence for the misclassification of Desulfotomaculum guttoideum and description of Desulfotomaculum orientis as Desulfosporosinus orientis gen. nov., comb. nov. Int J Syst Bacteriol 47, 1134-1139.

Stams, A. J. M., Kremer, D. R., Nicolay, K., Weenk, G. H. \& Hansen, T. A. (1984). Pathway of propionate formation in Desulfobulbus propionicus. Arch Microbiol 139, 167-173.

Stetter, K. O., Huber, R., Bloechl, E., Kurr, M., Eden, R. D., Fielder,
E., Cash, H. \& Vance, I. (1993). Hyperthermophilic archaea are thriving in deep North Sea and Alaskan oil reservoirs. Nature 365, 743-745.

Summit, M. \& Baross, J. A. (1998). Thermophilic subseafloor microorganisms from the 1996 North Gorda Ridge eruption. Deep-Sea Res Part II Top Stud Oceanogr 45, 2751-2766.

Tardy-Jacquenod, C., Magot, M., Patel, B. K. C., Matheron, R. \& Caumette, P. (1998). Desulfotomaculum halophilum sp. nov., a halophilic sulfate-reducing bacterium isolated from oil production facilities. Int J Syst Bacteriol 48, 333-338.

Thiermann, F., Akoumianaki, I., Hughes, J. A. \& Giere, O. (1997). Benthic fauna of a shallow-water gaseohydrothermal vent area in the Aegean Sea (Milos, Greece). Mar Biol 128, 149-159.

Widdel, F. \& Bak, F. (1992). Gram-negative mesophilic sulfatereducing bacteria. In The Prokaryotes, 2nd edn, pp. 3352-3378. Edited by A. Balows, H. G. Trüper, M. Dworkin, W. Harder \& K.-H. Schleifer. New York: Springer.

Zeikus, J. G., Dawson, M. A., Thompson, T. E., Ingvorsen, K. \& Hatchikian, E. C. (1983). Microbial ecology of volcanic sulphidogenesis: isolation and characterization of Thermodesulfobacterium commune gen. nov. and sp. nov. J Gen Microbiol 129, $1159-1169$ 